\title{
Dissolved oxygen dynamics in salt marsh pools and its potential impacts on fish assemblages
}

\author{
Kelly J. Smith ${ }^{1}$, Kenneth W. Able ${ }^{2, *}$ \\ ${ }^{1}$ Department of Biology, University of North Florida, 4567 St. Johns Bluff Road South, Jacksonville, Florida 32224-2661, USA \\ ${ }^{2}$ Marine Field Station, Institute of Marine and Coastal Sciences, Rutgers University, 800 c/o 132 Great Bay Boulevard, \\ Tuckerton, New Jersey 08087-2004, USA
}

\begin{abstract}
In order to determine the dynamics of dissolved oxygen (DO) in salt marsh pools and its effect on their respective fish assemblages, DO was measured in 5 high-salinity pools in a Spartina alterniflora marsh in southern New Jersey over ten $24 \mathrm{~h}$ periods, from 2 July to 22 October 1990, to determine daily and monthly fluctuations. Typically, DO peaked at approximately 16:00 h, and reached a minimum by about 05:00 h. The greatest variation occurred in mid-July, when DO ranged from over $20 \mathrm{ppm}$ at midday, to 0 ppm in the early morning. From mid- to late August, DO remained at very low concentrations $(<1.0 \mathrm{ppm})$ for long periods $(11.7 \pm 1.7 \mathrm{~h})$. DO concentrations varied among marsh pools, but there was no interaction between pool and time of day. The young-of-the-year (YOY) of the dominant 5 species of fishes in these pools were tested for tolerance and behavioral responses to low DO in laboratory aquaria. Fundulus heteroclitus survived the longest at low DO, and Menidia menidia was least tolerant. Aquatic surface respiration (ASR) was the primary behavioral response to low DO for all species tested. All species, including Cyprinodon variegatus, Lucania parva, and $M$. beryllina, survived at DO $<0.5 \mathrm{ppm}$ when they used ASR; however, when fish were denied access to the air-water interface, only $F$. heteroclitus was able to survive more than $1 \mathrm{~h}$. All species initiated ASR at ca. 1 ppm, with the exception of M. menidia, which began ASR at 2.6 ppm and survived only at higher concentrations of DO. In summary, although the salt marsh pools showed extreme diurnal variability in DO, with rapid drops from supersaturation to anoxic conditions, all of the fish species, with the exception of $M$. menidia, were well adapted to survive these fluctuations. This lack of tolerance to low DO by M. menidia may seasonally limit its occurrence in marsh pools, but this is not the case for the congener M. beryllina, or the other resident fishes.
\end{abstract}

KEY WORDS: Dissolved oxygen · Salt marshes $\cdot$ Pools $\cdot$ Killifishes $\cdot$ Silversides · Young-of-the-year Resale or republication not permitted without written consent of the publisher

\section{INTRODUCTION}

Hypoxic and anoxic conditions occur in many estuarine and marine systems (Diaz \& Rosenberg 1995, Diaz 2000, Wannamaker \& Rice 2000, Rabalais \& Turner 2001). In deeper estuarine systems, stratification and organic decay lead to large-scale anoxic events (Officer et al. 1984, Sanford et al. 1990, Breitburg 1992, Keister et al. 2000), which can be of long duration. Many shallow water systems and shallow water portions of deeper systems have shorter, often diel cycles in dissolved oxygen (DO; Kenney et al. 1988), with lowest levels observed in the early morning and high- est levels during the afternoon. This diel variation in DO is driven by autotrophic production of oxygen (Kenney et al. 1988), with relatively constant oxygen consumption. Hypoxia and anoxia are known to be significant factors in determining the distribution and habitat shifts (Pihl et al. 1991, Breitburg 1992, 1994, Howell \& Simpson 1994, Thiel et al. 1995), diet (Pihl et al. 1992), growth (Bejda et al. 1992, Peterson \& Pihl 1995, Phelan et al. 2000, Taylor \& Miller 2001), mortality (Breitburg et al. 1997, 1999), and community structure of estuarine and marine fauna (Tunnicliffe 1981). Fishes have a variety of adaptations to survive in hypoxic habitats, through both behavioral (Magnuson 
et al. 1985, Kramer 1987) and physiological changes (Greaney et al. 1980, Peterson 1990). Fish can react behaviorally to hypoxia and anoxia by increasing their ventilation rate (Kramer 1987, Pihl et al. 1991), moving out of areas of stress (Congleton 1980, Bejda et al. 1987, Breitburg 1992, Wannamaker \& Rice 2000) or by reducing activity levels (Fischer et al. 1992). Many shallow water fish initiate aquatic surface respiration (ASR) when DO drops to low levels (Gee et al. 1978, Kramer \& McClure 1981, Kramer 1983), and some species have morphological adaptations that increase the efficiency of ASR (Lewis 1970).

Salt marsh pools (also known as pannes or potholes) are a prominent feature of salt marshes along the NE Atlantic Coast of North America (Chapman 1960). Pools are permanent bodies of water that are flooded during spring and storm (Able et al. in review) high tides. Little is known about DO dynamics in these pools, although an earlier study indicated that DO can fluctuate over a wide range in the summer (Christian 1981). Marsh pools are important habitats for several species of fishes in the families Cyprinodontidae, Fundulidae and Atherinidae (Talbot et al. 1986, Smith \& Able 1994, Able et al. 1996), however we know relatively little about the responses of some of these species to rapid changes in DO, although responses to static DO levels have been observed (Voyer \& Hennekey 1972). Recently, the effect of abiotic and biotic factors on transient fishes was examined from some barrier island ponds (Layman et al. 2000). The goals of our study were to (1) examine changes in monthly and daily fluctuations in DO concentrations in salt marsh pools over summer and fall, when temperatures are warmest, and (2) test, in the laboratory, the tolerance and behavior of the dominant fishes found in these pools, in order to better understand the effect of low DO on the behavior and composition of fish assemblages.

\section{MATERIALS AND METHODS}

Field observations. Observations of salt marsh pools were made in the relatively unaltered Sheepshead Meadows salt marshes in the Jacques Cousteau National Estuarine Research Reserve at Mullica River, Great Bay (Psuty et al. 1993, Lathrop et al. 2000), a salt marsh peninsula near Tuckerton, New Jersey, USA $\left(39^{\circ} 30^{\prime} \mathrm{N}, 74^{\circ} 19^{\prime} \mathrm{W}\right.$; Fig. 1). Salt marsh pools selected were among those included in a concurrent study on fish distribution (Smith 1995). For the purposes of this paper we define salt marsh pools as sunken areas in the marsh, typically with vertical or overhanging edges (Pennings \& Bertness 2000). Many of the marsh pools have partially submerged clumps of algae (primarily of Cladophora sp. and blue greens; Moul 1958). The algae are temporally variable because they are dispersed with tidal innundation (author's pers. obs.). The dominant emergent vegetation in the study area was short-form Spartina alterniflora, and the dominant submerged aquatic vegetation in some of the salt marsh pools was Ruppia maritima (Table 1).

Five salt marsh pools were sampled biweekly from 2 July to 22 October in 1990 (Table 1, Fig. 1). Each of the 9 sampling days was initiated at 11:00 h Eastern Standard Time (EST), continued overnight and ended at 11:00 $\mathrm{h}$ EST on the following day, and is designated by the initiation date. Physical parameters (DO, temperature, salinity) were measured every $2 \mathrm{~h}$ for a total of 13 times each sampling day per pool (Fig. 1, Table 1). All pools were measured within a $30 \mathrm{~min}$ period to decrease the effects of time on differences in DO between pools, based on preliminary observations of its variability (Smith 1995). DO (ppm) and water temperature $\left({ }^{\circ} \mathrm{C}\right)$ were measured with a YSI Model 57 meter at both the surface and bottom of the water column, air temperature $\left({ }^{\circ} \mathrm{C}\right)$ with an alcohol field thermometer, and salinity $(\%)$ with an American Optical refractometer. At the start, middle, and end of each sampling run, water samples were collected and fixed for Winkler titration analysis, to check the YSI Model 57 meter measurements. Marsh pools were compared for variability in magnitude of DO change, and length of hypoxic period (DO < $1.0 \mathrm{ppm}$ ) over the entire sampling season using a 2-way ANOVA with pool and time-ofday as main effects.

Laboratory observations. Fish response to changing DO was determined in laboratory aquaria between 28 July and 4 August 1992. Previous field observations indicated fishes in 
Table 1. Characteristics of individual pools. Pool locations shown in Fig. 1. Surface area estimated from aerial photographs (Smith 1995). Physical characteristics indicated as mean \pm SE (range). Submerged aquatic vegetation was Ruppia maritima. DO: dissolved oxygen

\begin{tabular}{|c|c|c|c|c|c|c|c|}
\hline Pool & $\begin{array}{l}\text { Surface } \\
\text { area }\left(\mathrm{m}^{2}\right)\end{array}$ & $\begin{array}{l}\text { Depth } \\
\text { (cm) }\end{array}$ & $\begin{array}{c}\text { Submerged aquatic } \\
\text { vegetation }\end{array}$ & $\begin{array}{l}\text { Salinity } \\
(\%)\end{array}$ & $\begin{array}{l}\text { Water temperature } \\
\qquad\left({ }^{\circ} \mathrm{C}\right)\end{array}$ & $\begin{array}{l}\text { Surface DO } \\
\quad(p p m)\end{array}$ & $\begin{array}{l}\text { Bottom DO } \\
\quad(\mathrm{ppm})\end{array}$ \\
\hline 1 & 116 & $\begin{array}{l}30.2 \pm 5.9 \\
(24-45)\end{array}$ & Absent & $\begin{array}{l}29.9 \pm 0.3 \\
(20-35)\end{array}$ & $\begin{array}{c}23.7 \pm 0.4 \\
(15.5-32.8)\end{array}$ & $\begin{array}{l}5.5 \pm 0.5 \\
(0-20)\end{array}$ & $\begin{array}{l}4.1 \pm 0.4 \\
(0-18.4)\end{array}$ \\
\hline 5 & 37 & $\begin{array}{l}29.3 \pm 5.1 \\
(23-34)\end{array}$ & Absent & $\begin{array}{l}29.4 \pm 0.3 \\
(19-36)\end{array}$ & $\begin{array}{c}23.7 \pm 0.4 \\
(14.9-33.1)\end{array}$ & $\begin{array}{l}5.4 \pm 0.4 \\
(0-15.2)\end{array}$ & $\begin{array}{l}3.1 \pm 0.3 \\
(0-12.8)\end{array}$ \\
\hline 6 & 23 & $\begin{array}{l}38.6 \pm 3.7 \\
(36-45)\end{array}$ & Absent & $\begin{array}{l}29.3 \pm 0.2 \\
(24-32)\end{array}$ & $\begin{array}{c}23.6 \pm 0.4 \\
(14.5-32.6)\end{array}$ & $\begin{array}{l}4.6 \pm 0.4 \\
(0-20)\end{array}$ & $\begin{array}{l}3.3 \pm 0.3 \\
(0-14.8)\end{array}$ \\
\hline 8 & 128 & $\begin{array}{l}40.6 \pm 10 \\
(25-50)\end{array}$ & Present & $\begin{array}{l}29.3 \pm 0.2 \\
(22-33)\end{array}$ & $\begin{array}{l}23.7 \pm 0.4 \\
(15-32.2)\end{array}$ & $\begin{array}{c}6.3 \pm 0.4 \\
(0.1-14.9)\end{array}$ & $\begin{array}{l}4.6 \pm 0.4 \\
(0-17.3)\end{array}$ \\
\hline 10 & 70 & $\begin{array}{l}36.9 \pm 6 \\
(25-47)\end{array}$ & Absent & $\begin{array}{l}29.9 \pm 0.1 \\
(26-33)\end{array}$ & $\begin{array}{c}23.8 \pm 0.4 \\
(14.9-32.9)\end{array}$ & $\begin{array}{l}5.8 \pm 0.4 \\
(0-16.6)\end{array}$ & $\begin{array}{l}5.1 \pm 0.4 \\
(0-16.1)\end{array}$ \\
\hline
\end{tabular}

salt marsh pools would experience extreme fluctuations of DO during this period. The 5 dominant species of fishes (Cyprinodon variegatus, Fundulus heteroclitus, Lucania parva, Menidia beryllina, and M. menidia) collected on salt marsh surface habitats (Smith 1995, Able et al. 1996) were tested for behavioral responses and tolerance to naturally observed and rapid decreases in DO. Individuals were collected from salt marsh pools in the study area (Smith 1995) with quatrefoil plexi-glass traps (Secor et al. 1992). These traps served as passive collectors that prevented larger individuals from entering.

Fishes were maintained in the laboratory in large flow-through aquaria for 2 to $6 \mathrm{~d}$ prior to each experiment and fed Artemia and flake food. The water for the aquaria was drawn from Schooner Creek, a subtidal creek adjacent to the marsh pool sites (Fig. 1). Mean size and number of fish tested varied among species (Table 2) but all were young-of-the-year (YOY) based on length (Able 1990, Able \& Fahay 1998). Six 11.41 aquaria, with opaque partitions separating them, were placed on a table under fluorescent lights with a 14:10 $\mathrm{h}$ light:dark cycle. All aquaria were initially on flowthrough ambient water, but at the start of the experiment, flow-through was turned off and each aquarium was randomly assigned as either a control $(n=2)$ or a treatment $(n=4)$ condition. As a result, all aquaria started an experiment with the same water at the same water temperature and DO concentration. All fishes were acclimated to the experimental aquaria overnight, and each experiment was initiated at 06:00 h EST the following day. Fishes were not fed during the acclimation period or the experiment.
To provide low DO water for each experimental run, ambient water (30\% salinity) was run through a nitrogen stripping column to a level of $0.5 \mathrm{ppm}$ oxygen, and stored overnight. During the experiment, DO was decreased in treated aquaria through water changes of $1 / 3$ of the volume every $30 \mathrm{~min}$. Water was added and removed using stationary submerged hoses to minimize disturbance to the fish. Control aquaria received normoxic ambient water during similar water changes. Once DO decreased to $1 \mathrm{ppm}$, water changes were replaced by gentle bubbling of $\mathrm{N}_{2}$ through an air stone in treatment aquaria, and ambient air in control tanks. In the treated aquaria this continued to reduce DO to about $0.5 \mathrm{ppm}$. To decrease DO below this level, a plastic film was laid across the surface of the water of all aquaria to prevent diffusion across the air-water interface. Each run consisted of replicates of experimental and control aquaria for a single species. Experiments continued until at least $50 \%$ mortality occurred in each treatment aquarium. DO decreased at about the same rate for all experimental runs (Fig. 2). Counts of individuals exhibiting specific responses (e.g. swimming through the water column, surface skimming

Table 2. Experimental arrangement for dissolved oxygen tolerance studies of salt marsh pool fishes in $11.4 \mathrm{l}$ aquaria. Mean (range) of total lengths (TL) based on combined data from all tanks

\begin{tabular}{|lcccc|}
\hline Species & $\begin{array}{r}\text { No. per } \\
\text { aquaria }\end{array}$ & $\begin{array}{c}\text { No. } \\
\text { tested }\end{array}$ & $\begin{array}{c}\text { Mean TL } \\
\text { mm } \pm \text { SD }\end{array}$ & $\begin{array}{c}\text { Time period } \\
(\mathrm{h})\end{array}$ \\
\hline Cyprinodon variegatus & 8 & 48 & $24.8 \pm 5.1(13-31)$ & $06: 00-15: 30$ \\
Fundulus heteroclitus & 10 & 58 & $29.7 \pm 4.5(19-37)$ & $06: 00-18: 30$ \\
Lucania parva & 10 & 58 & $19.1 \pm 2.9(13-24)$ & $06: 00-16: 00$ \\
Menidia menidia & 10 & 60 & $31.2 \pm 3.2(25-37)$ & $06: 00-11: 00$ \\
Menidia beryllina & 10 & 57 & $23.3 \pm 3.1(18-30)$ & $06: 00-15: 30$ \\
\hline
\end{tabular}




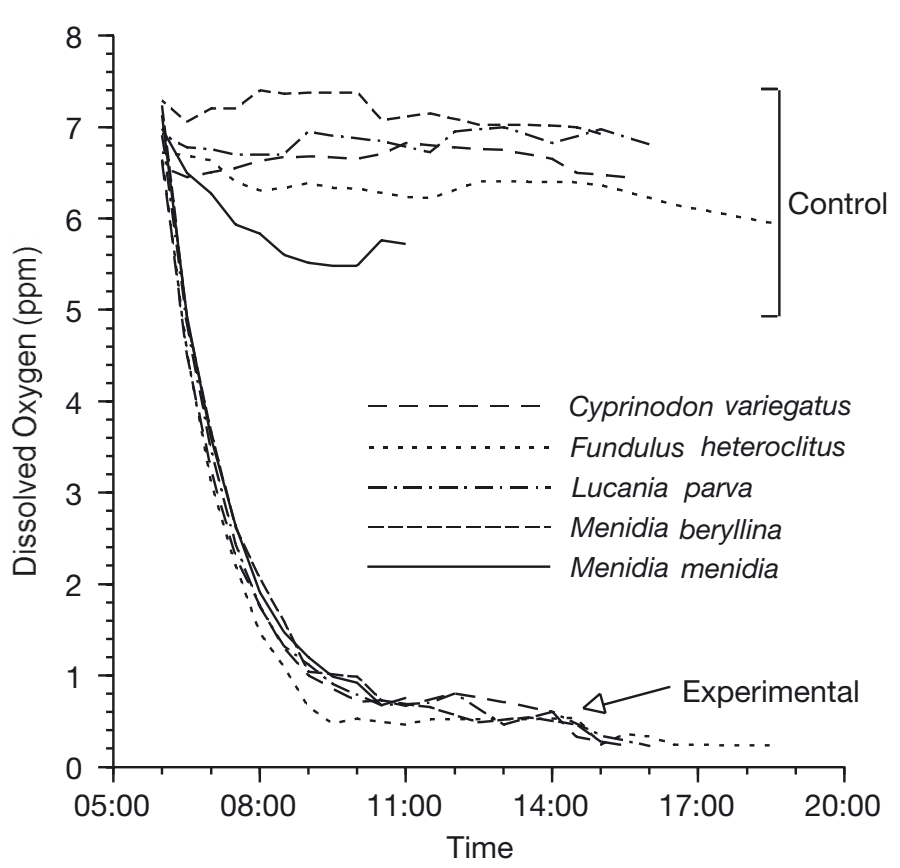

Fig. 2. Mean dissolved oxygen (DO) values relative to time during all experimental runs of the low tolerance experiment. Mean values were based on 4 replicates for experimental treatments, and 2 replicates for control treatments

[ASR], resting on the bottom, and presence of dead fish [no opercular activity]) were recorded separately for each aquarium ca. every $30 \mathrm{~min}$. Fish were observed through a blind during each experimental run to reduce disturbance by the observer. After each behavioral observation, DO and water temperature were recorded, and the water was adjusted as needed. A YSI Model 57 meter was used to measure DO, and at the start and end of each trial. In each instance the YSI probe was submerged, with care taken not to disturb the air-water interface. Water samples for Winkler titration analysis $(100 \mathrm{ml})$ were collected with a hose that was fixed inside each aquarium to check the YSI Model 57 meter measurements. Subsequent observations of fish behaviour were made $20 \mathrm{~min}$ after the water was tested in order to reduce the likelihood that the activity disturbed the fish.

Log linear analysis was used to test the effect of time on measured response variables (mortality, ASR, midwater swimming, resting on bottom). This analysis created a predicted response curve from the observed distribution of fishes among the 4 possible responses. A maximum likelihood ANOVA tested for significant effects of time on distribution patterns. Statistical analyses were conducted using the SAS 6.03 statistical package for personal computers (SAS Institute 1988).

\section{RESULTS}

\section{DO dynamics}

DO concentrations changed dramatically on a daily and monthly basis. Time of day significantly affected DO $\left(F_{12,520}=56.9, \mathrm{p}<0.0001\right)$, and DO was consistently cyclical for all the pools, peaking at ca. 16:00 $\mathrm{h}$, and reaching a minimum by ca. 05:00 h (Fig. 3). After sunrise, DO increased rapidly during the summer months; however, during late October, when temperatures were lower, the rate of increase was greatly reduced. The mean maximum value for all pools and all dates was $10.3 \pm 0.7 \mathrm{ppm}$ at 17:00 $\mathrm{h}$, and the mean minimum value was $1.02 \pm 0.3 \mathrm{ppm}$ at 05:00 h. The greatest range in DO occurred on 15-16 July, with values over $20 \mathrm{ppm}$ at midday to $0 \mathrm{ppm}$ in the early morning (Fig. 3). Individual pools varied in the magnitude of their diel DO cycles, and differences between pools did not remain constant over all dates. DO varied significantly among pools $\left(F_{4,520}=5.31, \mathrm{p}<0.001\right)$, and there was no interaction between pool and time of day $\left(F_{4,520}=0.53, \mathrm{p}<0.99\right)$. There were no significant differences between pools in length of period of DO below $1.0 \mathrm{ppm}\left(F_{4,40}=1.35, \mathrm{p}<0.27\right)$ or overall magnitude of DO values $\left(F_{4,40}=1.67, \mathrm{p}<0.18\right)$. Pool 1 tended to drop to lower oxygen levels at night, and remain low for long periods of time. Pool 8 was similar to other sites in peak oxygen values, but did not drop as low as the other sites at night.

Monthly variation in DO varied largely because values remained low for long periods of time during midand late August sampling dates (Fig. 3), from midnight until 07:00 h $(<1 \mathrm{ppm})$. During 12-13 August, DO ranged from 0 to $16 \mathrm{ppm}$ and remained below $1 \mathrm{ppm}$ for the longest period of time $(11.7 \pm 1.7 \mathrm{~h}$, Fig. 3$)$. Pools over the same dates also showed the most rapid rate of decrease in DO (1.3 ppm $\left.\mathrm{h}^{-1}\right)$. Extended low DO periods were also observed on 25 August for several pools. In September and October, daily DO variation leveled off, and although pools remained below $1 \mathrm{ppm}$ for several hours, they did not drop to $0 \mathrm{ppm}$ for longer than $4 \mathrm{~h}$.

\section{Fish behavior and mortality}

All species in the treatment aquaria responded to decreasing DO by moving from midwater to the water surface and using ASR (Fig. 4, Table 3), with the exception of Cyprinodon variegatus, which responded to decreasing DO by resting on the bottom of the aquaria (Fig. 4). Most species initiated ASR at approximately 1 ppm DO, but Menidia menidia started at $2.6 \mathrm{ppm}$ (Table 3). Attempts at ASR were continued by 


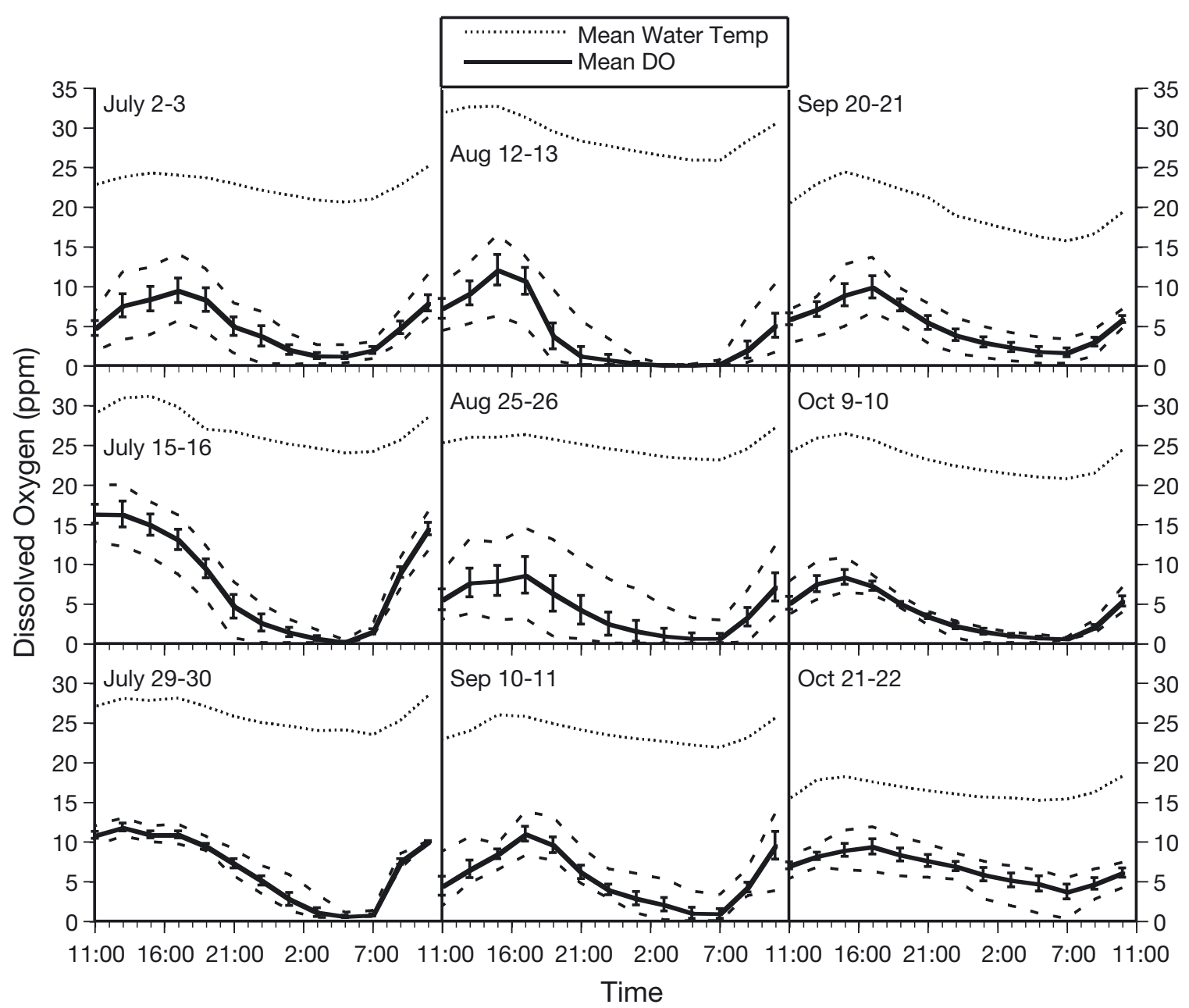

Fig. 3. Dissolved oxygen profiles for 5 salt marsh pools over 9 sample runs during 1990. Values are averaged ( \pm 1 SE), with minimum and maximum values. Mean surface water temperature is plotted for each date. Measurements were taken every $2 \mathrm{~h}$, beginning at 11:00 $\mathrm{h}$ EST and concluding at 11:00 $\mathrm{h}$ EST on the following day

all species even after the air-water interface was removed. Fish in control aquaria showed little or no change in response over the experimental period.

Decreasing DO significantly altered fish survival (Tables 3 \& 4, Fig. 4). Fundulus heteroclitus survived the longest under low oxygen conditions, up to $4 \mathrm{~h}$, with DO $<1.0 \mathrm{ppm}$ and no air-water interface. A mortality of $50 \%$ occurred in F. heteroclitus at a DO of $0.23 \pm 0.02 \mathrm{ppm}, 240 \mathrm{~min}$ after the air-water interface was removed. At the other extreme, Menidia menidia did not survive longer than 30 min once DO dropped below $1.0 \mathrm{ppm}$. This species was not tested with removal of the air-water interface. M. beryllina, Cyprinodon variegatus, and Lucania parva were all intermediate in survival time between $F$. heteroclitus (most tolerant), and M. menidia (least tolerant). No mortality of control fish occurred for $C$. variegatus, $F$. heteroclitus, or $M$. beryllina; however, $1 M$. menidia and 1 L. parva died in control aquaria.

\section{DISCUSSION}

Salt marsh pools in southern New Jersey undergo rapid and severe fluctuations in DO, comparable in magnitude to barrier island ponds in Virginia (Layman et al. 2000) and brackish ponds used in commercial fish culture (Szyper \& Ebeling 1993). The greatest range in DO and the longest hypoxic periods in New Jersey occur in midsummer (mid-July to late August), when oxygen production and consumption peak (Christian 1981). DO increases rapidly during the day from photosynthesis of benthic algae, phytoplankton and submerged aquatic vegetation, and decreases after nightfall when oxygen production ceases but oxygen consumption continues (Christian 1981). We observed supersaturated conditions (Ross et al. 2001), which can result from intense photosynthesis, during the midafternoon. Reductions in DO over time observed in this study are similar to those observed by Layman et al. 


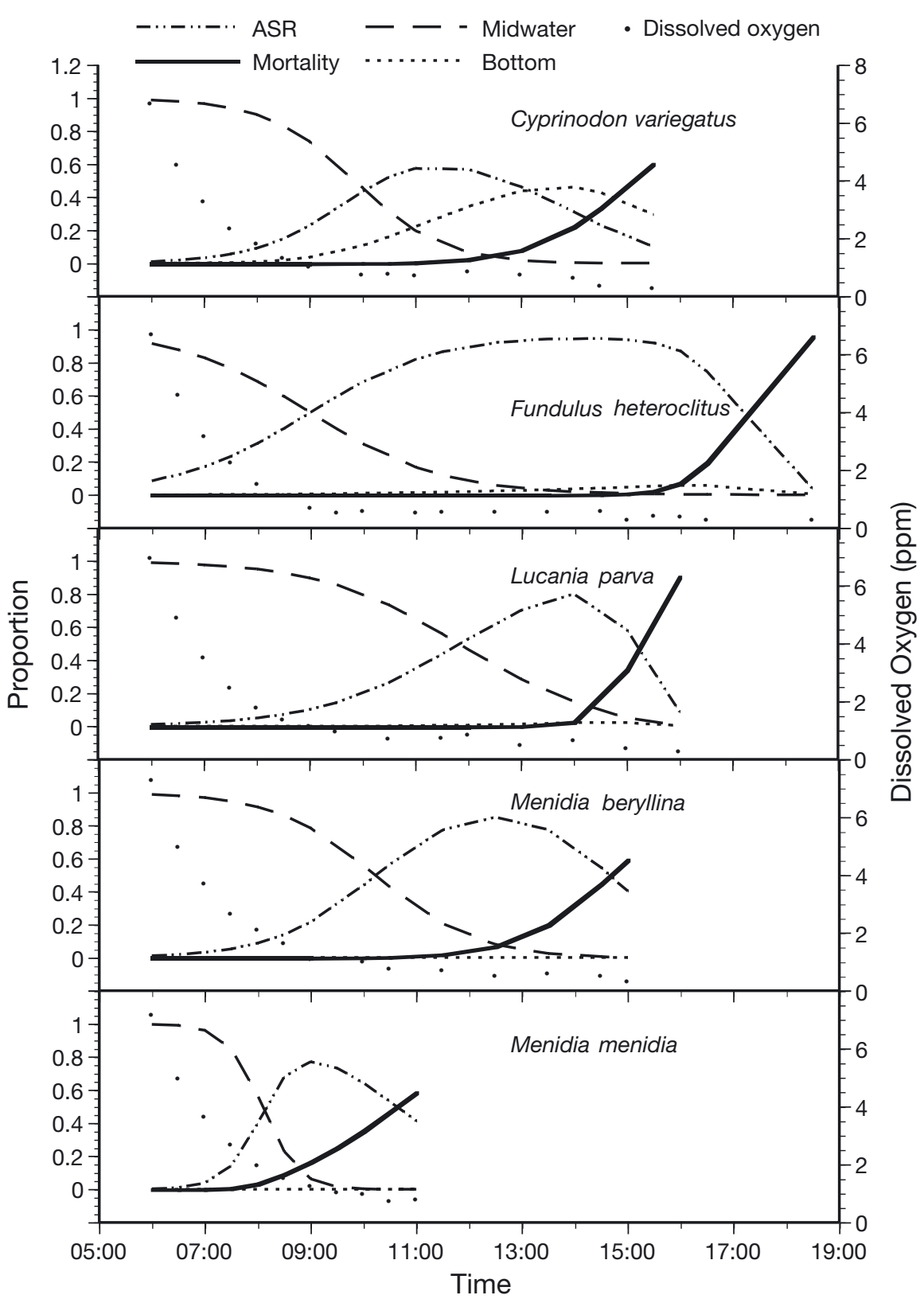

Fig. 4. Log-linear analysis predicted response patterns by marsh pool fish species in experimental treatments. See Table 2 for experimental arrangement. Responses over time, for all aquaria, presented as proportion of fish found either at the water surface (aquatic surface respiration; ASR), in midwater, resting on the bottom, or dead. Mean change in dissolved oxygen for all experimental replicates also shown. Experiments were concluded when at least $50 \%$ mortality occurred in each experimental tank

(2000) during the summer in Virginia barrier island ponds. Results from their field enclosure studies on fishes found in the barrier island ponds indicated that abiotic stresses such as low DO could contribute to higher mortalities in less tolerant surf-zone fish species.

Of the fish species we tested in the laboratory, Fundulus heteroclitus was the most tolerant of low DO, and is also the dominant species in salt marsh pools at the study site (Able et al. 1996), and in New Jersey (Talbot et al. 1986) and elsewhere in the NE USA (Collette \& Klein-MacPhee 2002). Layman et al. (2000) found similar dominance in abundance for this species in coastal Virginia ponds, and a similar tolerance to extremely low DO under laboratory conditions. Other laboratory studies have only tested relatively high levels of DO (2.4 to $7.5 \mathrm{mg} \mathrm{DO} \mathrm{l}^{-1}$; Voyer \& Hennekey 1972). Some of the other species tested (Cyprinodon variegatus, Lucania parva, Menidia beryllina) have somewhat lower tolerance to hypoxia. C. variegatus and L. parva 
Table 3. Summary of experimental conditions and fish responses for laboratory study on tolerance of low dissolved oxygen (DO). DO decrease values were natural log-transformed; all other DO values in ppm. Survival times are maximum estimates since observations were collected at ca. 30 min intervals. ASR = aquatic surface respiration. Time since air removal was the number of minutes when $50 \%$ of the fish survived after fish were denied access to the water surface by covering it with plastic sheeting

\begin{tabular}{|lcccccrrr|}
\hline Species & $\begin{array}{c}\text { DO } \\
\text { decrease }\end{array}$ & $\begin{array}{c}\text { Mean water } \\
\text { temp. } \\
\left({ }^{\circ} \mathrm{C}\right)\end{array}$ & $\begin{array}{c}\text { DO at } \\
\text { start of } \\
\text { ASR }\end{array}$ & $\begin{array}{c}\text { DO at } \\
\text { initial } \\
\text { mortality }\end{array}$ & $\begin{array}{c}\text { DO at } \\
50 \% \\
\text { mortality }\end{array}$ & $\begin{array}{c}\text { Time } \\
(\mathrm{min}) \\
\text { DO }<1.0\end{array}$ & $\begin{array}{r}\text { Time } \\
(\mathrm{min}) \\
\text { DO }<0.5\end{array} \begin{array}{c}\text { Time }(\mathrm{min}) \\
\text { since air } \\
\text { removal }\end{array}$ \\
\hline Cyprinodon variegatus & -0.277 & 24.0 & $1.00 \pm 0.01$ & $0.67 \pm 0.07$ & $0.33 \pm 0.03$ & 330 & 60 & 40 \\
Fundulus heteroclitus & -0.229 & 24.5 & $1.09 \pm 0.02$ & $0.36 \pm 0.03$ & $0.23 \pm 0.02$ & 570 & 540 & 240 \\
Lucania parva & -0.293 & 23.0 & $0.91 \pm 0.02$ & $0.34 \pm 0.09$ & $0.23 \pm 0.04$ & 390 & 180 & 60 \\
Menidia beryllina & -0.317 & 23.0 & $1.04 \pm 0.02$ & $0.49 \pm 0.03$ & $0.27 \pm 0.04$ & 300 & 150 & 30 \\
Menidia menidia & -0.467 & 22.5 & $2.64 \pm 0.10$ & $1.91 \pm 0.06$ & $0.76 \pm 0.02$ & 30 & N/A & N/A \\
\hline
\end{tabular}

are usually found in salt marsh pools, while $M$. beryllina is collected in both salt marsh pools (Able et al. 1996) and intertidal creeks (Bengston 1984, Rountree et al. 1992, Smith 1995, Able et al. 1996). M. beryllina may use the marsh pools as a nursery, since primarily juveniles have been collected in these habitats (Coorey et al. 1985, authors' unpubl. data). These 3 species are not as abundant in many of the shallow, muddy habitats that $F$. heteroclitus dominates.

Menidia menidia is very abundant in the surrounding intertidal and subtidal of the study area creeks, where it is the dominant species throughout the summer (Rountree \& Able 1992). During the same period, it makes movements on to the marsh surface (K. W. Able unpubl. data), based on video camera images near the marsh edge, and as a result is occasionally retained in marsh pools at low tide. This is the least tolerant species to low DO of the species tested, and was collected in marsh pools only in early July as YOY (total length $=29 \pm 0.8 \mathrm{~mm}$, K. J. Smith unpubl. data), when DO did not remain low for long periods of time (Fig. 3). This species becomes stressed when DO decreases to $2.6 \mathrm{ppm}$ (Table 3), a concentration twice as high as its congener, $M$. beryllina. $M$. menidia also has rapid metabolic and growth rates (Bengston 1984, Conover 1990), which may make it more prone to energetic constraints under low DO than is $M$. beryllina. The combination of low DO and high water temperature during mid- to late summer may explain the low abundance of $M$. menidia in these salt marsh pools, even though they are present as juveniles in the early summer. This pattern is similar to the response of the cofamilial Membras martinica (Layman et al. 2000).
The extremely low DO observed in the early morning in the salt marsh pools (Fig. 3) was well below lethal levels for many species of fish (Davis 1975), and has been shown to cause behavioral changes in several fishes (Kramer 1987, Beitinger 1990). Low DO conditions could influence fishes in a variety of ways. Low DO is likely to be stressful for spawning fish and their eggs; however, most of the dominant species in the marsh pools spawn prior to the season of lowest DO. Peak spawning occurs in May and June for most of the fundulids and cyprinodontids (Able 1990, Able \& Fahay 1998) and atherinids (Conover \& Ross 1982, Coorey et al. 1985), and during these dates low DO is less frequent and of shorter duration (authors' pers. obs.).

Low DO can increase mortality and affect species assemblages by changing predator-prey relationships (Kramer 1987), and these responses may occur in

Table 4. Summary of maximum likelihood ANOVA designed to test for effect of time on the observed distribution and survival of fishes. Degrees of freedom (df) calculated from number of behavioral responses. Chi-squared value computed for runs that showed more than 1 response (control runs for Cyprinodon variegatus, Fundulus heteroclitus, and Menidia beryllina only show midwater response). DO: dissolved oxygen

\begin{tabular}{|lccrrr|}
\hline Species & Treatment & Source & df & $\chi^{2}$ & $\mathrm{p}$ \\
\hline Cyprinodon variegatus & Low DO & Intercept & 3 & 171.59 & 0.001 \\
& & Time & & 159.10 & 0.001 \\
Fundulus heteroclitus & Low DO & Intercept & 3 & 210.78 & 0.001 \\
& & Time & & 202.33 & 0.001 \\
Lucania parva & Low DO & Intercept & 3 & 185.16 & 0.001 \\
& & Time & & 170.48 & 0.001 \\
& Control & Intercept & 1 & 2.73 & 0.10 \\
& & Time & & 1.96 & 0.16 \\
Menidia beryllina & Low DO & Intercept & 2 & 187.32 & 0.001 \\
& & Time & & 178.18 & 0.001 \\
Menidia menidia & Low DO & Intercept & 2 & 114.54 & 0.001 \\
& & Time & & 109.42 & 0.001 \\
& \multirow{2}{*}{ Control } & Intercept & 1 & 1.08 & 0.30 \\
& & Time & & 1.82 & 0.18 \\
& & & & & \\
& & &
\end{tabular}


marsh pools. If predatory fishes are not tolerant of low DO, small fishes may be less susceptible to such predators in low DO areas (Poulin et al. 1987, Breitburg et al. 1994), and habitats like marsh pools may therefore serve as refuges, at least from aquatic predators. In fact, these pools appear to serve as nurseries for YOY of all of the species in this assemblage with the exception of Menidia menidia (authors' unpubl. data). However, avian predation success also increases as DO decreases in some habitats (Kramer et al. 1983), and some birds concentrate their foraging activities in the early morning, when DO is low (Kersten et al. 1991). Increased bird foraging clearly occurs in the study area in late summer for a variety of species including herons, egrets, terns, and gulls (authors' pers. obs.). Since predation by herons, egrets, etc. is selective toward larger fish (Britton \& Moser 1982, Kneib 1982), low DO may cause a greater mortality for adults but marsh pools could still provide a refuge for smaller juveniles. This use of low DO habitats by prey species has also been observed in freshwater fish (Rosenberger \& Chapman 1999).

In summary, the extreme diurnal and seasonal variability in DO in natural salt marsh pools make these habitats environmentally harsh environments for most species of fish, and ASR is a common behavioral response. Alternatively, the reduction in aquatic predators afforded by these extreme conditions may be one factor influencing the use of marsh pools as a habitat by tolerant species. Direct mortality due to low DO and indirect mortality from increased susceptibility to predation may be important factors in determining the abundance and assemblage structure of fishes in natural salt marsh pools.

Acknowledgements. The authors would like to thank R. Christian for his advice and editorial review. L. Chapman kindly reviewed an earlier version of this manuscript. Numerous technicians and volunteers at Rutgers University Marine Field Station (RUMFS) assisted in the field collections. S. Hagan assisted with data compilation and analysis, and D. Witting and J. McLellan provided statistical advice. This study was supported through grants and scholarships from the Manasquan Marlin and Tuna Club, New Jersey Marine Sciences Consortium, Department of Biological Sciences (Leathem Fund), RUMFS, and the Institute for Marine and Coastal Sciences (IMCS), Rutgers University, and conducted under Rutgers University Animal Protocol 88-042. This paper is IMCS Contribution No. 2003-21.

\section{LITERATURE CITED}

Able KW (1990) Life history patterns of New Jersey salt marsh killifishes. Bull NJ Acad Sci 35:23-30

Able KW, Fahay MP (1998) The first year in the life of estuarine fishes in the Middle Atlantic Bight. Rutgers University Press, New Brunswick, NJ

Able KW, Witting DA, McBride RS, Rountree RA, Smith KJ
(1996) Fishes of polyhaline estuarine shores in Great Bay-Little Egg Harbor, New Jersey: a case study of seasonal and habitat influences. In: Nordstrom KF, Roman CT (eds) Estuarine shores: evolution, environments and human alterations. John Wiley \& Sons, Chichester, p 335-353

Beitinger TL (1990) Behavioral reactions for the assessment of stress in fishes. J Gt Lakes Res 16:495-528

Bejda AJ, Studholme AL, Olla BL (1987) Behavioral responses of red hake, Urophycis chuss, to decreasing concentrations of dissolved oxygen. Environ Biol Fish 19:261-268

Bejda AJ, Phelan BA, Studholme AL (1992) The effect of dissolved oxygen on the growth of young-of-the-year winter flounder Pseudopleuronectes americanus. Environ Biol Fish 34:321-327

Bengston DA (1984) Resource partitioning by Menidia menidia and $M$. beryllina (Osteichthyes: Atherinidae). Mar Ecol Prog Ser 18:21-30

Breitburg DL (1992) Episodic hypoxia in Chesapeake Bay: interacting effects of recruitment, behavior, and physical disturbance. Ecol Monogr 62:525-546

Breitburg DL (1994) Behavioral response of fish larvae to low dissolved oxygen concentrations in a stratified water column. Mar Biol 120:615-625

Breitburg DL, Steinberg N, DuBeau S, Cooksey C, Houde ED (1994) Effects of low dissolved oxygen on predation on estuarine fish larvae. Mar Ecol Prog Ser 104:235-246

Breitburg DL, Loher T, Pacey CA, Gerstein A (1997) Varying effects of low dissolved oxygen on trophic interactions in an estuarine food web. Ecol Monogr 67:489-507

Breitburg DL, Rose KA, Cowan JH (1999) Linking water quality to larval survival: predation mortality of fish larvae in an oxygen-stratified water column. Mar Ecol Prog Ser 178:39-54

Britton RH, Moser ME (1982) Size specific predation by herons and its effect on the sex-ratio of natural populations of the mosquito fish Gambusia affinis Baird and Girard. Oecologia 1982:146-151

Chapman VJ (1960) Salt marshes and salt deserts of the world. Leonard Hill, London

Christian RR (1981) Community metabolism of a salt-marsh pothole. Bull NJ Acad Sci 26:34-40

Collette BB, Klein-MacPhee G (2002) Bigelow and Schroeder's Fishes of the Gulf of Maine, 3rd edn. Smithsonian Institution Press, Washington, DC

Congleton JL (1980) Observations on the responses of some southern California tidepool fishes to nocturnal hypoxic stress. Comp Biochem Physiol 66A:719-722

Conover DO (1990) The relationship between capacity for growth and length of growing season: evidence for and implications of countergradient variation. Trans Am Fish Soc 119:416-430

Conover DO, Ross MR (1982) Patterns in seasonal abundance, growth and biomass of the Atlantic silverside, Menidia menidia, in a New England estuary. Estuaries 5:275-286

Coorey DN, Able KW, Shisler JK (1985) Life history and food habits of the inland silversides, Menidia beryllina, in a New Jersey salt marsh. Bull NJ Acad Sci 30:29-38

Davis JC (1975) Minimal dissolved oxygen requirements of aquatic life with emphasis on Canadian species: a review. J Fish Res Bd Can 32:2295-2332

Diaz RJ (2000) Overview of hypoxia around the world. J Environ Qual 30:275-281

Diaz RJ, Rosenberg R (1995) Marine benthic hypoxia: a review of its ecological effects and the behavioural responses of benthic macrofauna. Oceanogr Mar Biol Annu Rev 33:245-303 
Fischer P, Rademacher K, Kils U (1992) In situ investigations on the respiration and behaviour of eelpout Zoarces viviparus under short-term hypoxia. Mar Ecol Prog Ser 88: 181-184

Gee JH, Tallman RF, Smart HJ (1978) Reactions of some Great Plains fishes to progressive hypoxia. Can J Zool 56: 1962-1966

Greaney GS, Place AR, Cashon RE, Smith G, Powers DA (1980) Time course of changes in enzyme activities and blood respiratory properties of killifish during long-term acclimation to hypoxia. Phys Zool 53:136-144

Howell P, Simpson D (1994) Abundance of marine resources in relation to dissolved oxygen in Long Island Sound. Estuaries 17:394-402

Keister JE, Houde ED, Breitburg DL (2000) Effects of bottomlayer hypoxia on abundances and depth distributions of organisms in Patuxent River, Chesapeake Bay. Mar Ecol Prog Ser 205:43-59

Kenney BE, Litaker W, Duke CS, Ramus J (1988) Community oxygen metabolism in a shallow tidal estuary. Estuar Coast Shelf Sci 27:33-43

Kersten M, Britton RH, Dugan PJ, Hafner H (1991) Flock feeding and food intake in little egrets: the effects of prey distribution and behaviour. J Anim Ecol 60:241-252

Kneib RT (1982) The effects of predation by wading birds (Ardeidae) and blue crabs (Callinectes sapidus) on the population size structure of the common mummichog, Fundulus heteroclitus. Estuar Coast Shelf Sci 14:159-165

Kramer DL (1983) Aquatic surface respiration in the fishes of Panama: distribution in relation to risk of hypoxia. Environ Biol Fish 8:49-54

Kramer DL (1987) Dissolved oxygen and fish behavior. Environ Biol Fish 18:81-92

Kramer DL, McClure M (1981) Aquatic surface respiration, a widespread adaptation to hypoxia in tropical freshwater fishes. Environ Biol Fish 7:47-55

Kramer DL, Manley D, Bourgeois R (1983) The effect of respiratory mode and oxygen concentration on the risk of aerial predation in fishes. Can J Zool 61:653-665

Lathrop RG, Cole MB, Showalter RD (2000) Quantifying the habitat structure and spatial pattern of New Jersey (USA) salt marshes under different management regimes. Wetl Ecol Mange 8:163-172

Layman CA, Smith DE, Herod JD (2000) Seasonally varying importance of abiotic and biotic factors in marsh-pond fish communities. Mar Ecol Prog Ser 207:155-169

Lewis WMJ (1970) Morphological adaptations of cyprinodontoids for inhabiting oxygen deficient waters. Copeia 1970: 319-326

Magnuson JJ, Beckel AL, Mills K, Brandt SB (1985) Surviving winter hypoxia: behavioral adaptations of fishes in a northern Wisconsin winterkill lake. Environ Biol Fish 14: 241-250

Moul ET (1958) Ecological observation of pools in the salt marshes of New Jersey. In: Ragotzkie RA (ed) Proc Salt Marsh Conference, Marine Institute, University of Georgia, Sapelo Island. University of Georgia Press, Athens

Officer CB, Biggs RB, Taft JL, Cronin LE, Tyler MA, Boynton WR (1984) Chesapeake Bay anoxia: origin, development, and significance. Science 223:22-27

Pennings SC, Bertness MO (2000) Salt marsh communities. In: Bertness MD, Gaines SD, Hay MG (eds) Marine community ecology. Sinauer Associates, Sunderland, MA, p 289-316

Peterson JK, Pihl L (1995) Responses to hypoxia of plaice, Pleuronectes platessa, and dab, Limanda limanda, in the south-east Kattegat: distribution and growth. Environ Biol Fish 43:311-321

Peterson MS (1990) Hypoxia-induced physiological changes in 2 mangrove swamp fishes: sheepshead minnow, Cyprinodon variegatus Lacepede and sailfin molly, Poecilia latipinna (Lesueur). Comp Biochem Physiol 97A: $17-21$

Phelan BA, Goldberg R, Bejda AJ, Pereira J and 5 others (2000) Estuarine and habitat-related differences in growth rates of young-of-the-year winter flounder (Pseudopleuronectes americanus) and tautog (Tautoga onitis) in three northeastern estuaries. J Exp Mar Biol Ecol 247:1-28

Pihl L, Baden SP, Diaz RJ (1991) Effects of periodic hypoxia on distribution of demersal fish and crustaceans. Mar Biol 108:349-360

Pihl L, Baden SP, Diaz RJ, Schaffner L (1992) Hypoxiainduced structural changes in the diet of bottom feeding fish and crustacea. Mar Biol 112:349-361

Poulin R, Wolf NG, Kramer DL (1987) The effect of hypoxia on the vulnerability of guppies (Poecilia reticulata, Poeciliidae) to an aquatic predator (Astronotus ocellatus, Cichlidae). Environ Biol Fish 20:285-292

Psuty NP, De Luca MP, Lathrop R, Able KW, Whitney S, Grassle JF (1993) The Mullica River-Great Bay National Estuarine Research Reserve: a unique opportunity for research, preservation and management. In: Magoon OT, Wilson WS, Converse H, Tobin LT (eds) Coastal zone 1993, Vol 2. Proc 8th Symp Coastal and Ocean Management. American Society of Civil Engineers, New York, p $1557-1568$

Rabalais NN, Turner RE (2001) Coastal hypoxia: consequences for living resources and ecosystems. American Geophysical Union, Washington, DC

Rosenberger AE, Chapman LJ (1999) Hypoxic wetland tributaries as faunal refugia from an introduced predator. Ecol Freshw Fish 8:22-34

Ross SW, Dalton DA, Kramer S, Christensen BL (2001) Physiological (antioxidant) responses of estuarine fishes to variability in dissolved oxygen. Comp Biochem Physiol Part C 130:289-303

Rountree RA, Able KW (1992) Fauna of polyhaline subtidal marsh creeks in southern New Jersey: composition, abundance and biomass. Estuaries 15:171-185

Rountree RA, Smith KJ, Able KW (1992) Length frequency data for fishes and turtles from polyhaline subtidal and intertidal marsh creeks in southern New Jersey. Tech Rep 92-34. Institute of Marine and Coastal Sciences, Rutgers University, New Brunswick, NJ

Sanford LP, Sellner KG, Breitburg DL (1990) Covariability of dissolved oxygen with physical processes in the summertime Chesapeake Bay. J Mar Res 48:567-590

SAS Institute (1988) SAS/STAT user's guide, Release 60.3 edn. SAS Institute, Cary, NC

Secor DH, Dean JM, Hansbarger J (1992) Modification of the quatrefoil light trap for use in hatchery ponds. Prog Fish Cult 54:202

Smith KJ (1995) Processes regulating habitat use by salt marsh nekton in a southern New Jersey estuary. PhD thesis, Rutgers University, New Brunswick, NJ

Smith KJ, Able KW (1994) Salt marsh tide pools as winter refuges for the mummichog, Fundulus heteroclitus, in New Jersey. Estuaries 17:237-245

Szyper JP, Ebeling JM (1993) Photosynthesis and community respiration at three depths during a period of stable phytoplankton stock in a eutrophic brackish water culture pond. Mar Ecol Prog Ser 94:229-238

Talbot CW, Able KW, Shisler JK (1986) Fish species composi- 
tion in New Jersey salt marshes: effects of marsh alterations for mosquito control. Trans Am Fish Soc 115: 269-278

Taylor JT, Miller JM (2001) Physiological performance of juvenile southern flounder, Paralichthys lethostigma (Jordan and Gilbert 1884), in chronic and episodic hypoxia. J Exp Mar Biol Ecol 258:195-214

Thiel R, Sepulveda A, Kafemann R, Nellen W (1995) Environmental factors as forces structuring the fish community of the Elbe Estuary. J Fish Biol 46:47-69

Editorial responsibility: Kenneth Heck (Contributing Editor), Dauphin Island, Alabama, USA
Tunnicliffe V (1981) High species diversity and abundance of the epibenthic community in an oxygen-deficient basin. Nature 294:354-356

Voyer RA, Hennekey RJ (1972) Effects of dissolved oxygen on two life stages of the mummichog. Prog Fish-Cult 34(4): $222-225$

Wannamaker CM, Rice JA (2000) Effects of hypoxia on movements and behavior of selected estuarine organisms from the southeastern United States. J Exp Mar Biol Ecol 249(2): $145-163$

Submitted: October 23, 2001; Accepted: April 30, 2003

Proofs received from author(s): August 8, 2003 